Article

\title{
Improvement of the Pseudocapacitive Performance of Cobalt Oxide-Based Electrodes for Electrochemical Capacitors
}

\author{
Mojtaba Mirzaeian ${ }^{1,2, *}$, Nazym Akhanova ${ }^{3}$, Maratbek Gabdullin ${ }^{4}$, Zhanar Kalkozova ${ }^{3}$, \\ Aida Tulegenova ${ }^{3}\left(\mathbb{D}\right.$, Shyryn Nurbolat ${ }^{3}$ and Khabibulla Abdullin ${ }^{3, *(D)}$ \\ 1 School of Computing, Engineering and Physical Sciences, University of the West of Scotland, \\ Paisley PA1 2BE, UK \\ 2 Faculty of Chemistry and Chemical Technology, Al-Farabi Kazakh National University, Al-Farabi Avenue 71, \\ Almaty 050012, Kazakhstan \\ 3 National Nanotechnology Laboratory of Open Type (NNLOT), Al-Farabi Kazakh National University, \\ Al-Farabi Avenue 71, Almaty 050012, Kazakhstan; nazym@physics.kz (N.A.); zh.kalkozova@mail.ru (Z.K.); \\ tulegenova.aida@gmail.com (A.T.); shyryn0709@gmail.com (S.N.) \\ 4 Research Center of Renewable Energy and Nanotechnology, Kazakh-British Technical University University, \\ Tole bi st. 59, Almaty 050000, Kazakhstan; gabdullin@physics.kz \\ * Correspondence: Mojtaba.Mirzaeian@uws.ac.uk (M.M.); kh.abdullin@physics.kz (K.A.)
}

Received: 29 August 2020; Accepted: 1 October 2020; Published: 8 October 2020

check for updates

\begin{abstract}
Cobalt oxide nanopowders are synthesized by the pyrolysis of aerosol particles of water solution of cobalt acetate. Cobalt nanopowder is obtained by subsequent reduction of obtained cobalt oxide by annealing under a hydrogen atmosphere. The average crystallite size of the synthesized porous particles ranged from 7 to $30 \mathrm{~nm}$, depending on the synthesis temperature. The electrochemical characteristics of electrodes based on synthesized cobalt oxide and reduced cobalt oxide are investigated in an electrochemical cell using a $3.5 \mathrm{M} \mathrm{KOH}$ solution as the electrolyte. The results of electrochemical measurements show that the electrode based on reduced cobalt oxide $\left(\mathrm{Re}-\mathrm{Co}_{3} \mathrm{O}_{4}\right)$ exhibits significantly higher capacity, and lower Faradaic charge-transfer and ion diffusion resistances when compared to the electrodes based on the initial cobalt oxide $\mathrm{Co}_{3} \mathrm{O}_{4}$. This observed effect is mainly due to a wide range of reversible redox transitions such as $\mathrm{Co}(\mathrm{II}) \leftrightarrow \mathrm{Co}$ (III) and $\mathrm{Co}(\mathrm{III}) \leftrightarrow \mathrm{Co}(\mathrm{IV})$ associated with different cobalt oxide/hydroxide species formed on the surface of metal particles during the cell operation; the small thickness of the oxide/hydroxide layer providing a high reaction rate, and also the presence of a metal skeleton leading to a low series resistance of the electrode.
\end{abstract}

Keywords: cobalt oxide nanoparticles; reduced cobalt oxide; core-shell nanoparticles; electrode material; supercapacitor

\section{Introduction}

Energy in the form of electricity generated from renewable resources such as wind, tidal and solar energy will contribute prominently and play an important role in our future energy demands by: (i) offering enormous potential for powering our future systems to overcome the concerns associated with the future energy shortage due to the anticipated doubling of world energy consumption within the next 50 years [1] and (ii) the use of low-or even zero-emission energy sources to tackle the fundamental problems associated with the use of fossil fuels as the world strives to reduce greenhouse gas emissions. However the success and practicality of the employment of renewable energies as clean and efficient energy supplies in powering our future energy demands depend on the development and 
the design of versatile energy-storage/power-supply systems capable of storing and delivering energy with longer calendar and cycle lifetimes and with a wide range of power density and energy density to respond to the inherent intermittency of supply/and at the same time fulfil the continuous demands of contemporary applications.

Along with different energy storage/conversion technologies such as lithium-ion batteries and fuel cells, which are well suited to absorbing/releasing energy over long charge/discharge times in a flat voltage fashion [2], supercapacitors are also considered as an important class of energy storage technology which is intensively developed at the present day [1,3-5]. This technology is distinct from batteries and plays a central role in the energy storage-and-delivery spectrum by absorbing/delivering energy very quickly within short charge/discharge periods; it ensures the quality of power supply, and the safety and health of other energy storage technologies through peak shaving and load shifting voltage regulations in cases of power fluctuations and pulse power applications. Energy storage/delivery in supercapacitors is based on the storage and release of electric charges and according to the mechanism of charge storage, supercapacitors are classified as three main types: (i) electrical double layer capacitors (EDLC) in which electric charges are stored electrostatically at the electrode/electrolyte interface where the electrode materials are predominantly carbonaceous materials, (ii) pseudocapacitors (PC) in which electric charges are stored Faradaically through fast reversible redox reactions on the surface/or in shallow depth of the active materials, and (iii) asymmetric supercapacitors (ASCs), which consist of a battery-type Faradaic electrode (cathode) as an energy source and a capacitor-type electrode (anode) as a power source.

Predominantly, transition metal oxides are used as electrode material in supercapacitors and battery-type Faradaic electrodes for ASCs [6-13]; and the oxides of a variety of metals such as iron, nickel, cobalt, silver, manganese, copper and ruthenium have been intensely investigated for this purpose in recent years [14-22]. Ruthenium oxide, $\mathrm{RuO}_{2}$, has exhibited an extraordinary specific capacitance [23] and is considered as one of the most favorable transition metal oxide for pseudocapacitor applications, however despite its large specific capacitance and excellent electrochemical performance, the environmental toxicity and high cost of $\mathrm{RuO}_{2}$ have hindered its wider commercialization in the supercapacitor industry [24]. Other transition metal oxides have also shown promising performance as electrode materials for supercapacitors, but their electrochemical properties yet need to be improved to meet the requirement of commercial applications.

Different methods such as (i) the hydrothermal method [25-28]; (ii) template method [29-31] and (iii) sol-gel method [32-34] have been employed to improve the porous structure and surface area of metal oxide nanoparticles. In the case of supercapacitors, the mesoporous structured transition metal oxides are favorable for specific capacitance by facilitating fast redox processes and providing a large specific surface which is beneficial for electrode/electrolyte contact on the electrochemically active sites. The use of metal oxide nanoparticles in the manufacture of electrodes for electrochemical capacitors is a fairly common practice and a promising route to achieve high storage capacity. In order to increase the storage capacity of supercapacitors, composite electrodes based on carbon materials (activated carbon, carbon nanotubes, graphene, etc.), which provide a high specific surface area combined with heteroatoms or nanoparticles of metal oxides, which exhibit a pseudocapacitive effect are also developed [34-38], although utilizing graphene and achieving good dispersion might not be particularly cost effective. Further to these other approaches in which an oxide layer is coated on a metal plate using magnetron sputtering or electrodeposition techniques, the formation of transition metal oxide-based electrodes is also practiced and applied in the manufacture of electrolytic capacitors [19,39-43].

Due to its many benefits such as fast redox reactions, high reversibility, relatively high surface-to-volume ratio, ease of preparation, green and eco-friendly nature, good chemical strength, wide range of morphological characteristics and a significant theoretical capacity of $3560 \mathrm{~F} \mathrm{~g}^{-1}$, cobalt oxide $\mathrm{Co}_{3} \mathrm{O}_{4}$ is considered as a promising material as an electrode material for pseudocapacitors and ASCs [44-51]. However, its practical capacitance is far below and is yet to reach its theoretical 
value due to its slow electron kinetics, fast capacity decay and impaired morphologies during its redox electrochemical reactions [51].

Thus, numerous efforts are being made to increase the electrochemical activity of electrode materials based on metal oxides [52,53], in particular, on the basis of cobalt oxide as a viable electrode material for supercapacitors [44-49,53-55]. In this article we demonstrate a new effect of enhancing the electrochemical activity of the $\mathrm{Co}_{3} \mathrm{O}_{4}$ electrode as a result of hydrogen reduction of the oxide to metal and the subsequent formation of core-shell structure by forming a thin oxide/hydroxide layer obtained by the in situ electrochemical oxidation of the cobalt nanoparticles surface. This new and simple method of enhancing electrochemical activity is mainly related to the redox activity of electroactive material.

\section{Experiment}

Cobalt oxide nanopowders were prepared by the pyrolysis of aerosol of aqueous solutions of $0.06 \mathrm{M}$ and $0.12 \mathrm{M}$ cobalt acetate tetrahydrate $\mathrm{Co}\left(\mathrm{CH}_{3} \mathrm{COO}\right)_{2} \cdot 4 \mathrm{H}_{2} \mathrm{O}(\mathrm{AcCo})$. The aerosol was obtained using a piezo ultrasonic atomizer. The mist of aerosol droplets was transferred by air stream into a tubular furnace heated to a temperature between 300 and $550{ }^{\circ} \mathrm{C}$ at a flow rate of about $1 \mathrm{~L} \mathrm{~min}{ }^{-1}$. The cobalt oxide particles formed in the hot zone of the furnace were carried by the gas stream into an electrostatic filter. The temperature of the filter was maintained at $\sim 200{ }^{\circ} \mathrm{C}$ to prevent water vapor condensing on the walls of the electrostatic filter. The synthesized powder trapped by the filter was collected for further investigation.

Samples of metal particles of cobalt were obtained by thermal hydrogen reduction of the cobalt oxide synthesized using $0.06 \mathrm{M}$ AcCo solution. The reduction was carried out in a quartz furnace at a temperature in the range of $200-300^{\circ} \mathrm{C}$ for between 1 and $2 \mathrm{~h}$, and the samples then were cooled down to the room temperature. The entire process was performed under hydrogen flowing at $60 \mathrm{~mL} \mathrm{~min}{ }^{-1}$.

X-ray diffraction (XRD) analysis was carried out by a MiniFlex Rigaku diffractometer with current and voltage kept at $15 \mathrm{~mA}$ and $40 \mathrm{kV}$, respectively, using $\mathrm{Cu} \mathrm{K} \alpha$ radiation to study the crystalline structure of the samples and identify their crystalline phases and their chemical composition. Raman spectra were taken by a Ntegra Spectra (NT-MDT) spectrometer with a 473-nm solid-state exciting laser in the range of $100-2600 \mathrm{~cm}^{-1}$ to investigate the chemical composition and crystallinity of the cobalt oxide samples synthesized at different temperatures. The surface morphology and microstructure of the samples were studied using a Quanta 3D 200i FEI scanning electron microscope (SEM). All electrochemical measurements including cyclic voltammetry (CV), galvanostatic charge/discharge (GCD) and electrochemical impedance spectroscopy (EIS) were performed using an Elins P-40X potentiostat in conjunction with an FRA-24M electrochemical impedance measurement module in a conventional three-electrode electrochemical cell. A platinum electrode was used as the counter electrode along with $\mathrm{Ag} / \mathrm{AgCl}$ electrode as the reference electrode. An electrode using a sample of cobalt oxide or reduced cobalt oxide as the electroactive material was used as the working electrode where a $3.5 \mathrm{M} \mathrm{KOH}$ solution was used as the electrolyte. CV measurements were used as the most appropriate method for characterizing redox processes during the cell operation. $\mathrm{CV}$ measurements were performed in the potential range of $\pm 0.5 \mathrm{~V}$ at a scan rate of $50 \mathrm{mV} \mathrm{s}^{-1}$. EIS measurements were performed at $\mathrm{AC}$ amplitude of $100 \mathrm{mV}$ in the frequency range of 1-100 KHz. All cell measurements were performed at room temperature.

In order to prepare the working electrodes, $0.05 \mathrm{~g}$ of a powdered sample was added to $3 \mathrm{~mL}$ of ethanol and processed in an ultrasonic bath for almost $30 \mathrm{~min}$ until a homogeneous suspension was obtained, which was then deposited on a $5 \mathrm{~mm} \times 12 \mathrm{~mm}$ nickel foam substrate. It should be noted that the initial cobalt oxide powder had very good wettability; as a result, a stable suspension was formed while the reduced cobalt oxide powders clumped together significantly and the suspension of the reduced powders in ethanol was unstable and quickly precipitated.

The powdered sample on the nickel foam substrate was dried and pressed under a pressure of $\sim 10^{8} \mathrm{~Pa}$. Subsequent treatment of the electrode in ethanol in an ultrasonic bath for $10 \mathrm{~min}$ was 
performed in order to remove any weakly attached particles from the electrode. The sample mass was determined as a difference between the mass of the manufactured electrode and the initial mass of the substrate.

\section{Results and Discussion}

Figure 1 shows the XRD patterns of the samples obtained by the pyrolysis of cobalt acetate aerosol at the synthesis temperatures of $T_{\text {syn }}=300{ }^{\circ} \mathrm{C}$ and $550{ }^{\circ} \mathrm{C}$. Only XRD peaks of $\mathrm{Co}_{3} \mathrm{O}_{4}$ (JCPDS card No-00-043-1003) were detected as shown in Figure 1. The average crystallite size estimated from the XRD patterns using a MiniFlex Rigaku diffractometer processing program based on the Williamson-Hall method [56] was $25 \AA$ for the sample synthesized at $300{ }^{\circ} \mathrm{C}$ and $97 \AA$ for the sample synthesized at $550^{\circ} \mathrm{C}$.

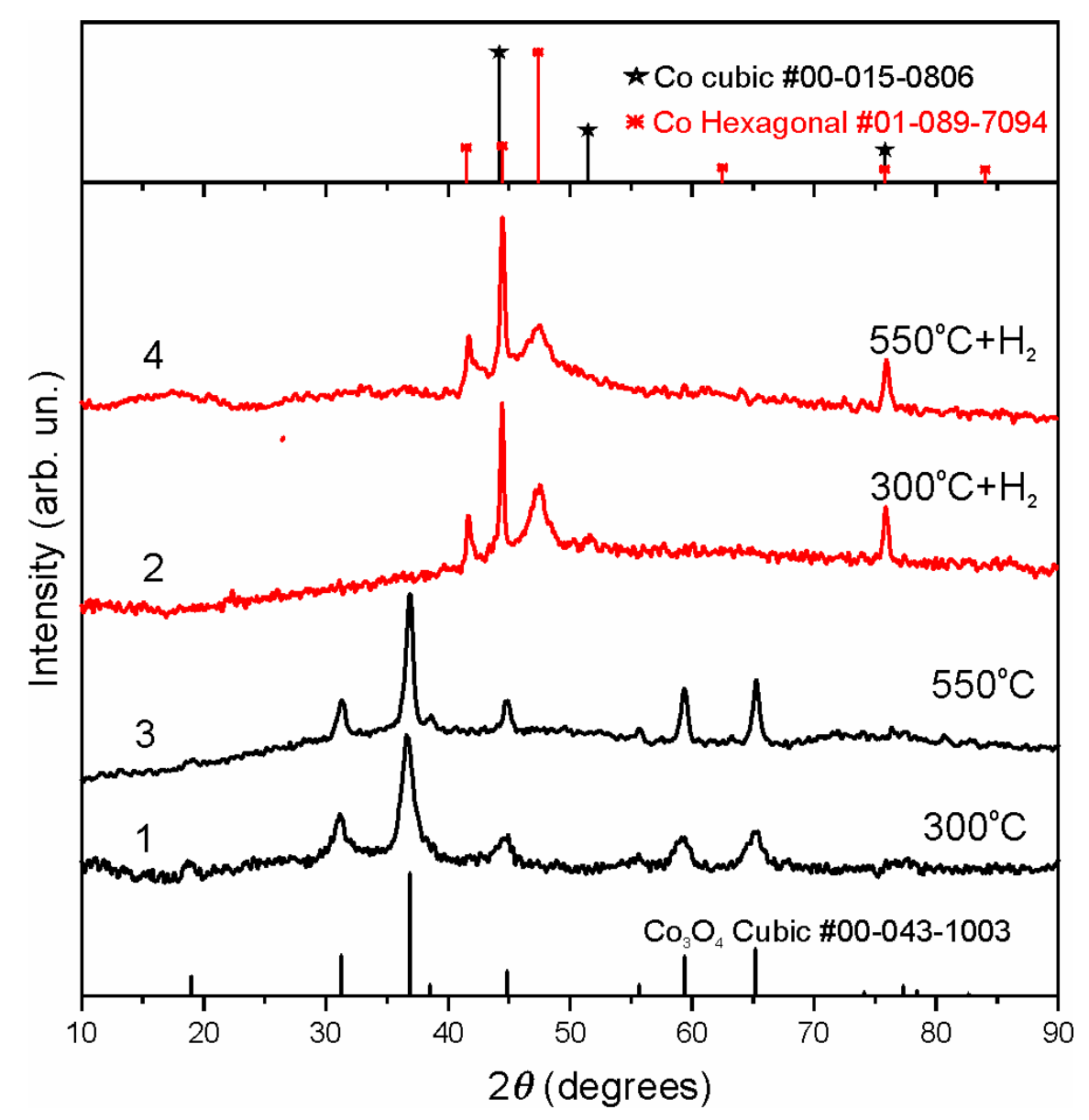

Figure 1. $\mathrm{XRD}$ patterns of the cobalt oxide $\left(\mathrm{Co}_{3} \mathrm{O}_{4}\right)$ samples synthesized at the temperature of $300{ }^{\circ} \mathrm{C}$ (1) and $550{ }^{\circ} \mathrm{C}(3)$ and annealed in hydrogen at $300{ }^{\circ} \mathrm{C}(\mathbf{2}, \mathbf{4})$.

The obtained cobalt oxide powder was then reduced by annealing in hydrogen atmosphere. XRD studies showed (Figure 1) that annealing at temperatures as low as $250-300{ }^{\circ} \mathrm{C}$ results in the complete disappearance of the $\mathrm{Co}_{3} \mathrm{O}_{4}$ phase and the appearance of metallic cobalt phase, consisting of a mixture of cubic and hexagonal cobalt (PDF cart \#00-015-0806 and \#01-089-7094, respectively).

The SEM images of the cobalt oxide nanoparticles synthesized by the pyrolysis of AcCo solutions with different concentrations given in Figure 2a,b show that the samples form almost round islands with little coalescence between them with clean surfaces. The size of $\mathrm{Co}_{3} \mathrm{O}_{4}$ nanoparticles decreases with a decrease in the concentration of AcCo solution leading to a more compacted structure with strong competition for space at the grain boundaries due to the accommodation of smaller particles in the 
vicinity of each other. The SEM micrographs of $\mathrm{Co}_{3} \mathrm{O}_{4}$ nanoparticles synthesized at different synthesis temperatures are given in Figure 2c,d and as seen the size of nanoparticles is weakly dependent on the synthesis temperature $T_{\text {syn }}$.
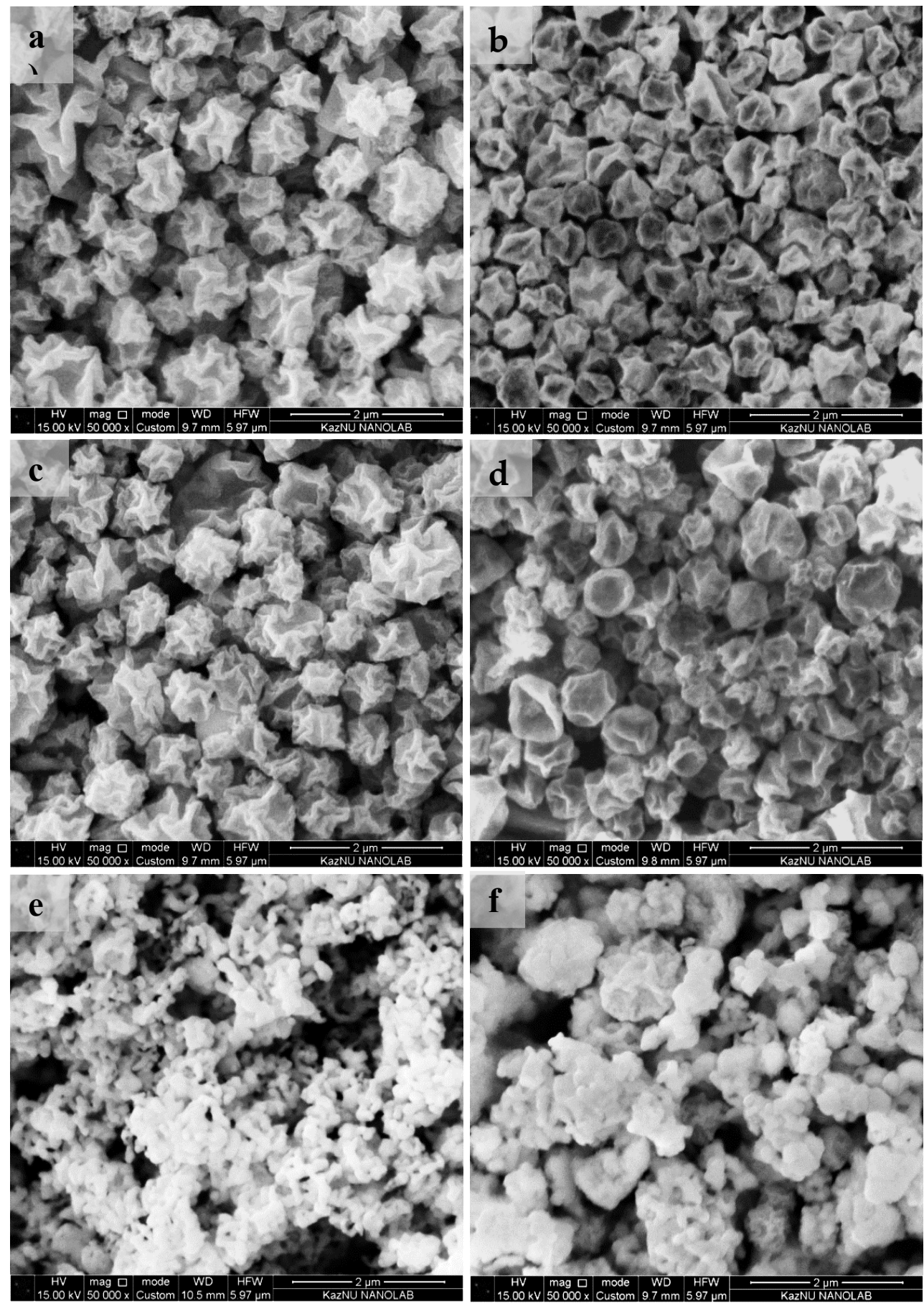

Figure 2. SEM images of $\mathrm{Co}_{3} \mathrm{O}_{4}$ and reduced $\mathrm{Co}_{3} \mathrm{O}_{4}$ nanoparticles obtained by: the pyrolysis of (a) a $0.12-\mathrm{M}$ solution of cobalt acetate tetrahydrate $\mathrm{Co}\left(\mathrm{CH}_{3} \mathrm{COO}\right)_{2} \cdot 4 \mathrm{H}_{2} \mathrm{O}(\mathrm{AcCo})$ and $(\mathbf{b})$ a $0.06-\mathrm{M}$ solution of AcCo at $500{ }^{\circ} \mathrm{C}$. The pyrolysis of a $0.12-\mathrm{M}$ solution of $\mathrm{AcCo}$ at the synthesis temperatures of: (c) $500{ }^{\circ} \mathrm{C}$ and (d) $350{ }^{\circ} \mathrm{C}$. The hydrogen annealing of the $\mathrm{Co}_{3} \mathrm{O}_{4}$ powder synthesized from the pyrolysis of a 0.06-M solution of AcCo at $350{ }^{\circ} \mathrm{C}$ at the temperatures of: (e) $250{ }^{\circ} \mathrm{C}$ and (f) $300{ }^{\circ} \mathrm{C}$. 
Figure 2e,f show the morphology of the $\mathrm{Re}-\mathrm{Co}_{3} \mathrm{O}_{4}$ samples synthesized at $350{ }^{\circ} \mathrm{C}$ and then reduced by annealing in hydrogen atmosphere for $1 \mathrm{~h}$ at $250{ }^{\circ} \mathrm{C}$ and $300{ }^{\circ} \mathrm{C}$, respectively. The SEM images of the annealed samples show amorphous-like clusters where the size of clusters increases with increasing the annealing temperature. According to XRD data, these samples consist of metallic cobalt. An enlargement of particle size and their sticking take place, and as seen the sintering process accelerates with increasing the reduction temperature. This clearly leads to a decrease in the surface area of the annealed sample. On the study of the cobalt oxide and its activity in the reduced form used as catalyst for the preparation of synthetic liquid fuels from hydrogenation of carbon monoxide, Shults et al. have shown that surface area of the cobalt oxide decreases 20-fold (from 67 to $3.2 \mathrm{~m}^{2} \mathrm{~g}^{-1}$ ) upon hydrogen reduction mainly due to the sintering, shrinkage and reorientation of the reduced cobalt [57].

The Raman spectra of the $\mathrm{Co}_{3} \mathrm{O}_{4}$ samples synthesized at different temperatures are shown in Figure 3. The detected Raman bands at 193.3, 474.6, 518.9, 611.7, and $679.8 \mathrm{~cm}^{-1}$ belong to the characteristics Raman-active $3 \mathrm{~F}_{2 \mathrm{~g}}, \mathrm{E}_{\mathrm{g}}, 2 \mathrm{~F}_{2 \mathrm{~g}}, 1 \mathrm{~F}_{2 \mathrm{~g}}$, and $\mathrm{A}_{1 \mathrm{~g}}$, respectively, which are related to the vibration modes of cobalt oxide [58]. The normal (unshifted) Raman bands of $\mathrm{Co}_{3} \mathrm{O}_{4}$ at room temperature appear at 197, 485, 523, 624, and $693 \mathrm{~cm}^{-1}$ [59]. The main Raman bands of $\mathrm{Co}_{3} \mathrm{O}_{4}$ samples obtained at $300-550{ }^{\circ} \mathrm{C}$ exhibit a red shift up to $30 \mathrm{~cm}^{-1}$ and more relative to the normal Raman bands of $\mathrm{Co}_{3} \mathrm{O}_{4}$ prepared at a temperature range of $250-500{ }^{\circ} \mathrm{C}$ given in Table 1 . The noticeable red shift of the Raman bands observed in all samples is typical for both single and agglomerated cobalt oxide nanoparticles and is caused by high laser power [60]. Thus, lowering the synthesis temperature increases the Raman band width and red shift, which indicates a decrease in crystallite size. This is consistent with the XRD results.

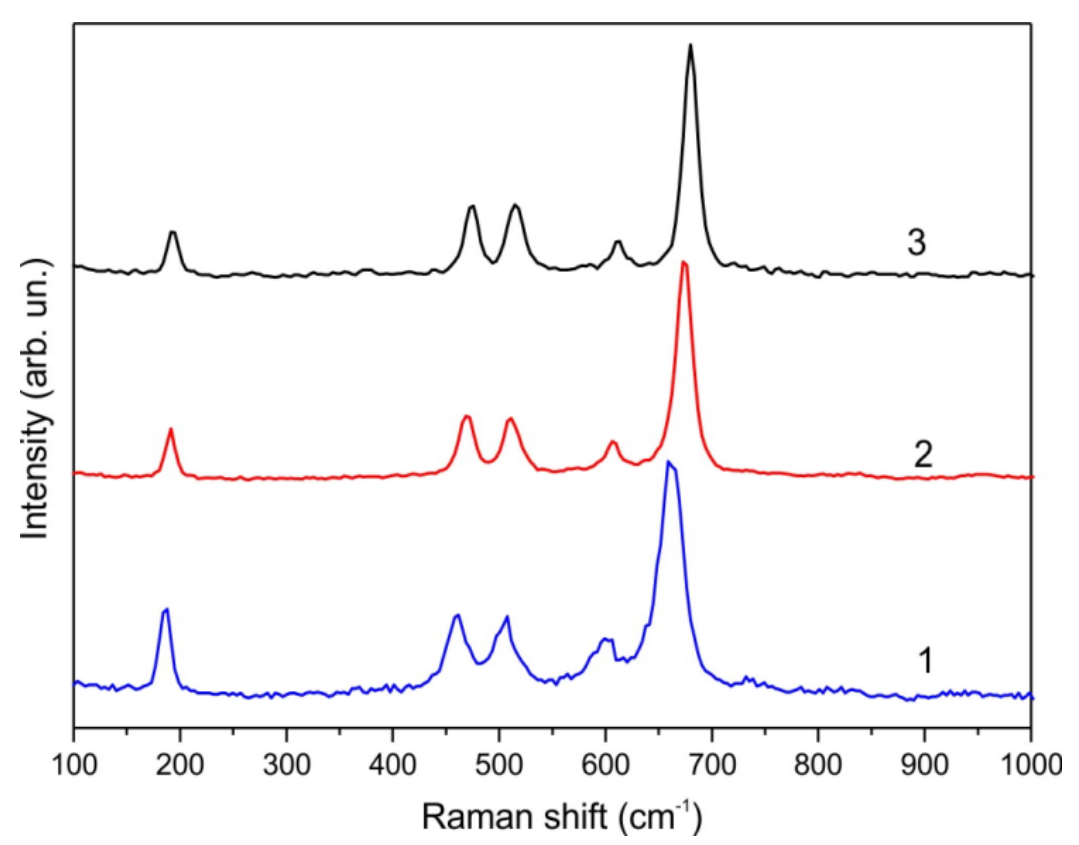

Figure 3. Raman spectra of cobalt oxide synthesized at different temperatures. (1) $250{ }^{\circ} \mathrm{C},(2) 350{ }^{\circ} \mathrm{C}$, (3) $500{ }^{\circ} \mathrm{C}$.

Table 1. Positions of the Raman peaks $\left(\mathrm{cm}^{-1}\right)$ for the samples synthesized at different temperatures $T_{\text {syn }}$ compared with the literature data [59].

\begin{tabular}{ccccccc}
\hline & Ref [59] & $\mathbf{1 9 7}$ & $\mathbf{4 8 5}$ & $\mathbf{5 2 3}$ & $\mathbf{6 2 4}$ & $\mathbf{6 9 3}$ \\
\hline $\mathbf{1}$ & $T_{\text {syn }}=250^{\circ} \mathrm{C}$ & 184 & 462 & 508 & 596 & 659 \\
\hline $\mathbf{2}$ & $T_{\text {syn }}=350^{\circ} \mathrm{C}$ & 191 & 469 & 511 & 606 & 675 \\
\hline $\mathbf{3}$ & $T_{\text {syn }}=500^{\circ} \mathrm{C}$ & 193 & 475 & 519 & 612 & 680 \\
\hline
\end{tabular}


The electrochemical performance of the electrodes prepared from the synthesized $\mathrm{Co}_{3} \mathrm{O}_{4}$ and reduced $\mathrm{Co}_{3} \mathrm{O}_{4}\left(\mathrm{Re}-\mathrm{Co}_{3} \mathrm{O}_{4}\right)$ samples was investigated by cyclic voltammetry $(\mathrm{CV})$, electrochemical impedance spectroscopy (EIS) and galvanostatic charge-discharge (GCD) measurements using the electrodes as the working electrode in a conventional three-electrode electrochemical cell with a $3.5 \mathrm{M}$ $\mathrm{KOH}$ solution used as the electrolyte. Typical CV curves at a scan rate of $50 \mathrm{mV} \mathrm{s}^{-1}$ for the $\mathrm{C}_{3} \mathrm{O}_{4}$ electrode (curve 1) and the $\mathrm{Re}-\mathrm{C}_{3} \mathrm{O}_{4}$ electrode (curve 2) are presented in Figure 4. The $\mathrm{Co}_{3} \mathrm{O}_{4}$ sample demonstrates two anodic peaks (A1 and A2) in the potential range of $0.2-0.4 \mathrm{~V}$ and the corresponding cathodic peaks denoted as $\mathrm{C} 1$ and $\mathrm{C} 2$. Anodic peaks $\mathrm{A} 1$ and $\mathrm{A} 2$ and corresponding cathodic peaks $\mathrm{C} 1$ and $\mathrm{C} 2$ can be attributed to the $\mathrm{Co}^{2+} \rightarrow \mathrm{Co}^{3+}$ and $\mathrm{Co}^{3+} \rightarrow \mathrm{Co}^{4+}$ reversible redox transitions, respectively. The two redox couples observed in the $\mathrm{CV}$ curves can be attributed to the following redox reactions according to the $\mathrm{CV}$ curves of the $\mathrm{C}_{3} \mathrm{O}_{4}$ electrode in an alkaline solution reported in Samal et al. and Premlatha et al. works [61,62]:

$$
\begin{gathered}
\mathrm{Co}_{3} \mathrm{O}_{4}+\mathrm{H}_{2} \mathrm{O}+\mathrm{OH}^{-} \rightleftharpoons 3 \mathrm{CoOOH}+\mathrm{e}^{-} \\
\mathrm{CoOOH}+\mathrm{OH}^{-} \rightleftharpoons \mathrm{CoO}_{2}+\mathrm{H}_{2} \mathrm{O}+\mathrm{e}^{-}
\end{gathered}
$$

The first reaction is $\mathrm{Co}^{2+} \leftrightarrow \mathrm{Co}^{3+}$ transformation (redox pair A1 and C1) that involves a reversible intercalation of $\mathrm{OH}^{-}$into the reduced form of $\mathrm{Co}_{3} \mathrm{O}_{4}$, forming $\mathrm{CoOOH}$ and leading to an improved charge storage capability of the electrode through pseudocapacitance. This is followed by a second reaction that is $\mathrm{Co}^{3+} \leftrightarrow \mathrm{Co}^{4+}$ transformation (redox pair A2 and C2) as a result of the adsorption of $\mathrm{OH}^{-}$ ions on the near-surface and the formation of $\mathrm{CoO}_{2}$ during the reduction process. It corresponds to an irreversible non-faradaic process that still contributes to the capacitance. Samal et al. and Premlatha et al. have also observed similar redox peaks for the electrochemical activity of cobalt oxide in alkaline electrolytes [61,62]. Such redox couples are typical for the cyclic voltammetry of cobalt oxide and are in good agreement with other published works [63-66].

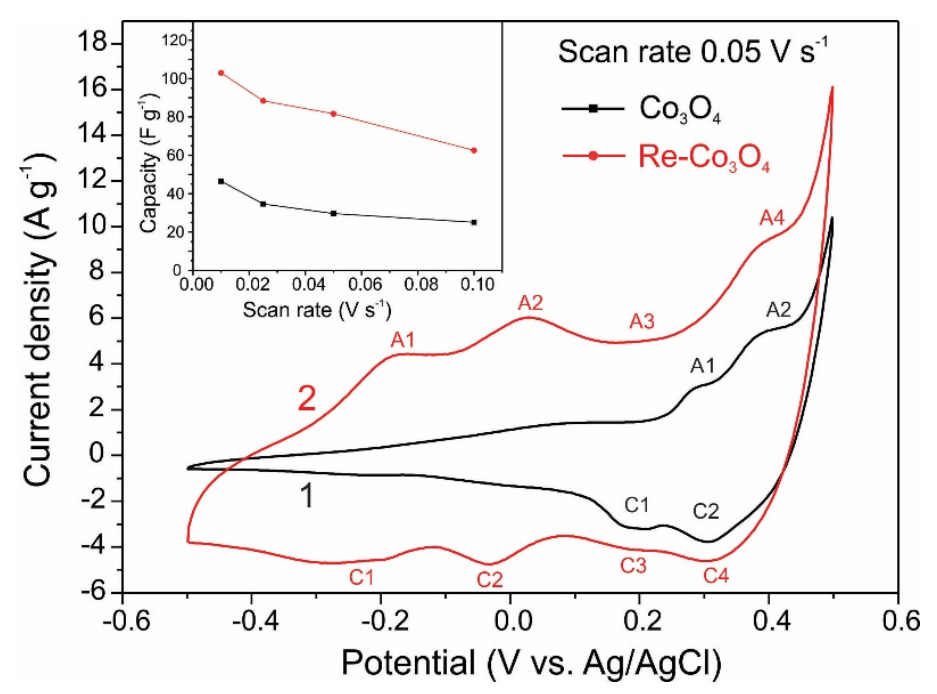

Figure 4. Cyclic voltammetry (CV) curves of $\mathrm{Co}_{3} \mathrm{O}_{4}(\mathbf{1})$ and reduced cobalt oxide $\left(\mathrm{Re}-\mathrm{Co}_{3} \mathrm{O}_{4}\right)$ (2) samples at a scan rate of $50 \mathrm{mV} \mathrm{s}^{-1}$ in a $3.5 \mathrm{M} \mathrm{KOH}$ aqueous solution. The inset shows the plot of capacity $\mathrm{Cs}$ versus potential scan rate for $\mathrm{Co}_{3} \mathrm{O}_{4}(\mathbf{1})$ and $\mathrm{Re}-\mathrm{Co}_{3} \mathrm{O}_{4}(2)$ electrodes.

Annealing of $\mathrm{Co}_{3} \mathrm{O}_{4}$ samples in hydrogen results in a significant change in their electrochemical properties. As can be seen in Figure 4, the $\mathrm{Re}-\mathrm{Co}_{3} \mathrm{O}_{4}$ sample displays a CV curve with four anodic peaks A1-A4 and the corresponding cathodic peaks $\mathrm{C} 1-\mathrm{C} 4$ in the potential range of -0.25 to $+0.4 \mathrm{~V}$.

A number of oxidation states of cobalt in alkaline medium are stable, so different oxide/hydroxide species of $\mathrm{Co}(\mathrm{II})$ such as $\mathrm{Co}(\mathrm{OH})_{2}$ and $\mathrm{CoO} ; \mathrm{Co}(\mathrm{II}, \mathrm{III})-\mathrm{Co}_{3} \mathrm{O}_{4} ; \mathrm{Co}(\mathrm{III})-\mathrm{Co}_{2} \mathrm{O}_{3}$ and $\mathrm{Co}(\mathrm{OH})_{3} ; \mathrm{Co}(\mathrm{IV})-\mathrm{CoO}_{2}$ can be formed on metallic cobalt surface and involved in the electrochemical processes and different 
studies have confirmed this [67-69]. The formation of the oxide layer on the surface of the metal electrode is a well-known process and this process is repeatedly described for different metals in the literature [70-73]. Although all the reports on the electrochemical formation of cobalt oxide films are based on the formation of the oxide directly on a bare electrode, studies of the anodic formation of cobalt oxide in alkaline solutions suggest that the anodic oxide film is $\mathrm{CoO}$ and/or $\mathrm{Co}(\mathrm{OH})_{2}$ at relatively low potentials and changes to $\mathrm{Co}_{3} \mathrm{O}_{4}$ and $\mathrm{Co}_{2} \mathrm{O}_{3}$ (or $\left.\mathrm{CoOOH}\right)$ at relatively high potentials. The presence of $\mathrm{CoO}_{2}$ has also been suggested in the oxygen evolution potential region [74]. Consequently, the formation of both oxide and hydroxide compounds on the metallic cobalt surface provides a wide range of redox reactions and increases the electrochemical activity of the Re- $\mathrm{Co}_{3} \mathrm{O}_{4}$ electrode. Due to a wider extent of the redox activity of the $\mathrm{Re}-\mathrm{Co}_{3} \mathrm{O}_{4}$ sample leading to the large number of redox peaks as observed in $\mathrm{CV}$ curves, the capacity of the reduced $\mathrm{C}_{3} \mathrm{O}_{4}$ sample is much higher than that of the initial $\mathrm{C}_{3} \mathrm{O}_{4}$ sample. Peaks at high potential $(\sim 0.2-0.4 \mathrm{~V})$ correspond to oxide spices, and peaks at low potential (from $-0.2 \mathrm{~V}$ ) correspond to hydroxide spices. Peaks at low potential have very low intensity in the initial sample since the sample consists of a thick layer of cobalt oxide, and there are few hydroxide spices. After $\mathrm{H}_{2}$ reduction, all oxides transform into the metal, and a highly dispersed conductive electrode is formed. Then during in situ oxidation in the electrolyte, a thin layer consisting of a mixture of oxide and hydroxide grows on a metal surface, since there is a lack of oxygen and the presence of hydrogen. Therefore, additional processes of hydroxide recharging make a significant contribution and expand the range of possible redox reactions. A significant advantage is that this layer is very thin, and it is all involved in redox processes. In the study of pseudocapacitive behavior of different metal oxides for high-rate electrochemical energy storage, Augustyn et al. have also shown that thin layers exhibit more pseudo-capacitive behavior and can achieve very high specific capacitances [75].

Similar redox couples with good reversibility have been detected in the voltammetric profile of cobalt hydroxide nanosheet electrodes by Ji et al. [76], on the cyclic voltammograms of cobalt-nickel double hydroxide-based electrodes obtained through cathodic electrodeposition by Xiao et al. [77], and also on the CV curves of cobalt/nickel layered double hydroxides prepared through a facile one-step solvothermal method by Chu and his co-workers [78]. They have explained these redox peaks by the following Faradaic reactions:

$$
\begin{gathered}
\mathrm{Co}(\mathrm{OH})_{2} \rightleftharpoons \mathrm{CoOOH}+\mathrm{H}^{+}+\mathrm{e}^{-} \\
\mathrm{CoOOH} \rightleftharpoons \mathrm{CoO}_{2}+\mathrm{H}^{+}+\mathrm{e}^{-}
\end{gathered}
$$

Therefore, the observed redox couples at low potentials on the $\mathrm{CV}$ curves for reduced $\mathrm{Co}_{3} \mathrm{O}_{4}$ electrode in this work shown in Figure 4 can be attributed to the Faradaic activities originated from the in situ oxidation and reduction of cobalt hydroxide and reversible transformation between different hydroxide spices, and these spices are located very close to the surface.

As seen in Figure 4 the redox couples on the CV curves of $\mathrm{Re}-\mathrm{Co}_{3} \mathrm{O}_{4}$ electrode shift towards lower voltages compared with those of $\mathrm{Co}_{3} \mathrm{O}_{4}$ electrode presumably as a result of the formation of $\mathrm{Co}(\mathrm{OH})_{2}$. In their study on electrocatalytic performance evaluation of cobalt hydroxide and cobalt oxide thin films for oxygen evolution reaction, Babar et al., also found that $\mathrm{Co}(\mathrm{OH})_{2}$ has much higher current density and lower over-potential than $\mathrm{Co}_{3} \mathrm{O}_{4}$ [79]. The specific capacitance for the electrodes can be calculated using $\mathrm{CV}$ curves on the basis of following equation:

$$
C_{s}=\frac{1}{2 m v\left(V_{\max }-V_{\min }\right)} \oint I(V) d V
$$

where, $C_{s}$ is the specific capacitance $\left(\mathrm{F} \mathrm{g}^{-1}\right), m$ is the mass of the electroactive material of the electrode $(\mathrm{g}), v$ is the scan rate $\left(\mathrm{V} \mathrm{s}^{-1}\right), V_{\max }-V_{\min }$ is the potential window $(\mathrm{V}), I$ is the current $(\mathrm{A})$ and integration is performed over one $\mathrm{CV}$ cycle. The plot of $C_{s}$ versus scan rate for both $\mathrm{Co}_{3} \mathrm{O}_{4}$ and $\mathrm{Re}-\mathrm{Co}_{3} \mathrm{O}_{4}$ electrodes is shown as the inset in Figure 4. 
It is known (Augustyn et al. [75]) that the peak current $\mathrm{i}$ in CV curves can be represented as a function of the sweep rate $\mathrm{v}$ as $\mathrm{i}=a v^{b}$, where $\mathrm{b}=0.5$ corresponds to battery material with diffusion-controlled redox reactions, and $\mathrm{b}=1$ corresponds to surface controlled capacitive current. The data on the dependence of the A1-C1 peak current in $\mathrm{Co}_{3} \mathrm{O}_{4}$ and $\mathrm{A} 2-\mathrm{C} 2$ in $\mathrm{Re}-\mathrm{Co}_{3} \mathrm{O}_{4}$ on the scanning speed (Figure 5) allow us to estimate the parameter $b$. In both cases, the $b$ value is in the range of 0.9-1.0, which indicates the predominance of capacitive currents at a sweep rate of at least more than $0.025 \mathrm{~V} \mathrm{~s}^{-1}$.
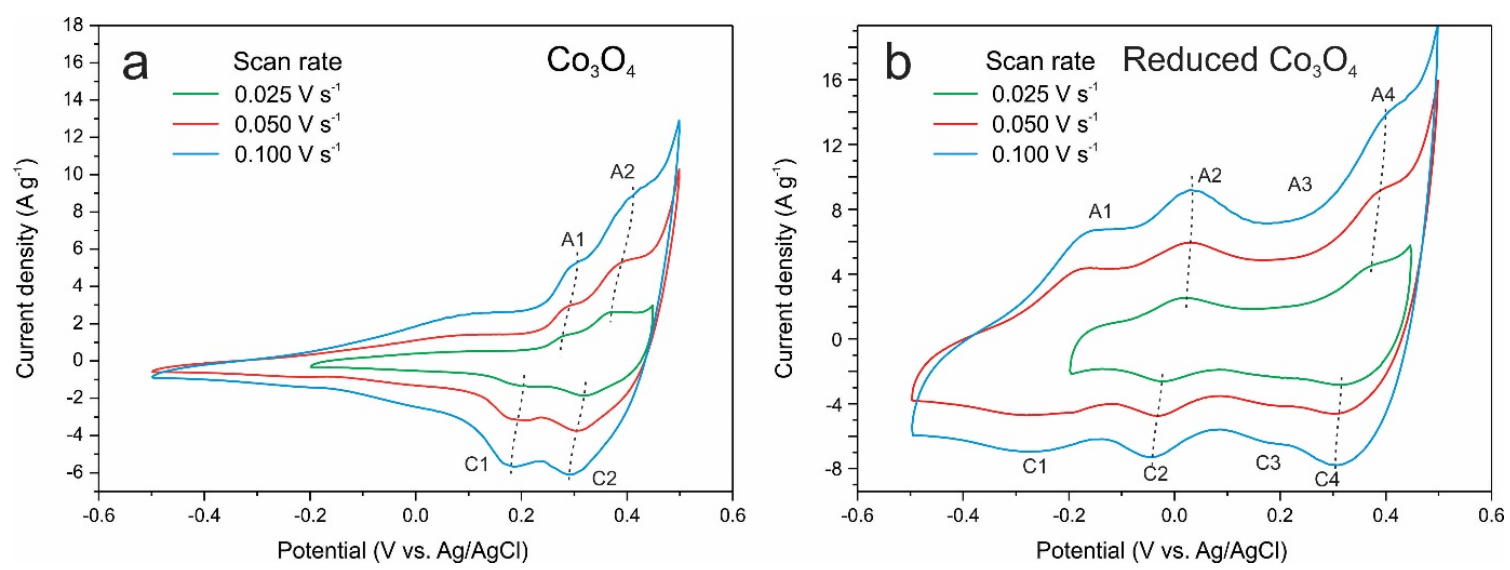

Figure 5. $\mathrm{CV}$ curves of $\mathrm{Co}_{3} \mathrm{O}_{4}(\mathbf{a})$ and $\mathrm{Re}-\mathrm{Co}_{3} \mathrm{O}_{4}(\mathbf{b})$ samples at scan rates from 25 to $100 \mathrm{mV} \mathrm{s}$ in a 3.5-M KOH aqueous solution.

It is also known that the surface pseudocapacitance is characterized by a small potential difference between the $\mathrm{CV}$ peaks of the charging and discharging steps (Augustyn et al. [75]). Figure 5 shows that the difference of the potentials between the oxidation and reduction peaks $\mathrm{A} 1-\mathrm{C} 1$ in $\mathrm{Co}_{3} \mathrm{O}_{4}$ is 0.078 , 0.103 and $0.125 \mathrm{~V}$ at scan rate of $0.025,0.050$ and $0.100 \mathrm{~V} \mathrm{~s}^{-1}$, correspondingly. At the same time, for new oxidation-reduction peaks A2-C2 (Figure 5b) that emerge on the CV curves of $\mathrm{Re}^{-} \mathrm{Co}_{3} \mathrm{O}_{4}$, which are absent in the initial sample, the difference of the potential is $0.035,0.061$, and $0.082 \mathrm{~V}$, respectively. It can also be noted that the potential difference between the $\mathrm{CV}$ peaks of the charging and discharging steps for peaks A4-C4 (Figure 5b) also increases much more slowly with increasing scanning speed than for the corresponding peaks A2-C2 in Figure 5a. This indicates that the new states in $\mathrm{Re}^{-} \mathrm{Co}_{3} \mathrm{O}_{4}$ are of a more surface-like nature.

The improved capacity of the Re- $\mathrm{Co}_{3} \mathrm{O}_{4}$ sample compared to $\mathrm{Co}_{3} \mathrm{O}_{4}$ is further confirmed by galvanostatic charge-discharge measurements (GCD), as shown in Figure 6. The capacity of the electrodes is calculated by the following equation:

$$
\begin{gathered}
Q=\int \frac{I}{m} d t \\
C=\frac{Q}{\Delta U}
\end{gathered}
$$

where $Q$ is the charge stored (expressed in $\mathrm{mA} \mathrm{h} \mathrm{g}^{-1}$ ), $I$ the discharge current $(\mathrm{A}), t$ the discharge time (s), $C$ the specific capacity $\left(\mathrm{F} \mathrm{g}^{-1}\right)$ and $\Delta \mathrm{U}$ voltage drop. In this case the $\mathrm{Re}-\mathrm{Co}_{3} \mathrm{O}_{4}$ sample exhibits a capacity of $60.2 \mathrm{~mA} \mathrm{~h} \mathrm{~g}^{-1}$ or $\sim 509.6 \mathrm{~F} \mathrm{~g}^{-1}$ at a current density of $0.38 \mathrm{~A} \mathrm{~g}^{-1}$ while the $\mathrm{Co}_{3} \mathrm{O}_{4}$ sample shows a much lower capacity of $11.4 \mathrm{~mA} \mathrm{~h} \mathrm{~g}^{-1}$ or $\sim 91.3 \mathrm{~F} \mathrm{~g}^{-1}$ at a current density of $0.24 \mathrm{~A} \mathrm{~g}^{-1}$ (Figure 6). Although the capacity is not as high, as will be shown below, the stability of the capacity during cycling is very high. 


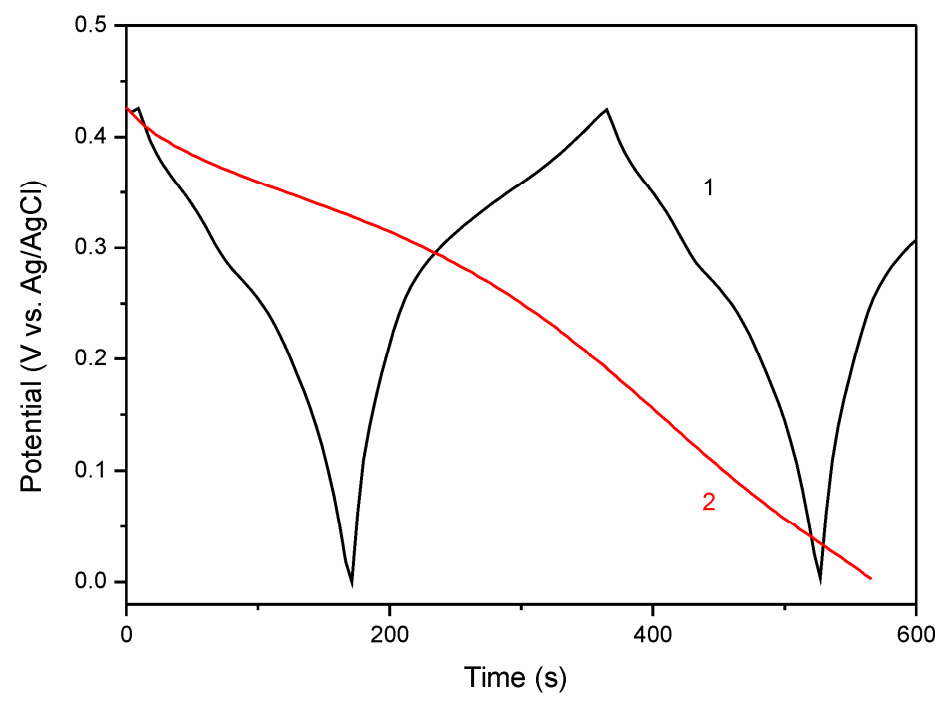

Figure 6. The galvanostatic charge/discharge (GCD) curves of $\mathrm{Co}_{3} \mathrm{O}_{4}(\mathbf{1})$ and $\mathrm{Re}-\mathrm{Co}_{3} \mathrm{O}_{4}(\mathbf{2})$ electrodes at current density of $0.24 \mathrm{~A} \mathrm{~g}^{-1}$ and $0.38 \mathrm{~A} \mathrm{~g}^{-1}$, respectively.

The electrochemical impedance of the samples was also measured in the frequency range of 1-10 $0^{5} \mathrm{~Hz}$ for further comparison of the $\mathrm{Co}_{3} \mathrm{O}_{4}$ and $\mathrm{Re}-\mathrm{Co}_{3} \mathrm{O}_{4}$ electrodes. The Nyquist plots for both $\mathrm{Co}_{3} \mathrm{O}_{4}$ and $\mathrm{Re}-\mathrm{CO}_{3} \mathrm{O}_{4}$ samples shown in Figure 7 consist of a high-frequency semicircle and an almost straight line in the low-frequency section. The semicircle is associated with charge-transfer resistance $\left(R_{\mathrm{ct}}\right)$, and the straight line is attributed to the process of diffusion of ions from the electrolyte into the electrode. The Re- $\mathrm{Co}_{3} \mathrm{O}_{4}$ electrode has a smaller semicircle than the $\mathrm{Co}_{3} \mathrm{O}_{4}$ sample, meaning that the Re- $\mathrm{Co}_{3} \mathrm{O}_{4}$ electrode has a lower charge transfer resistance $R_{\mathrm{ct}}$.

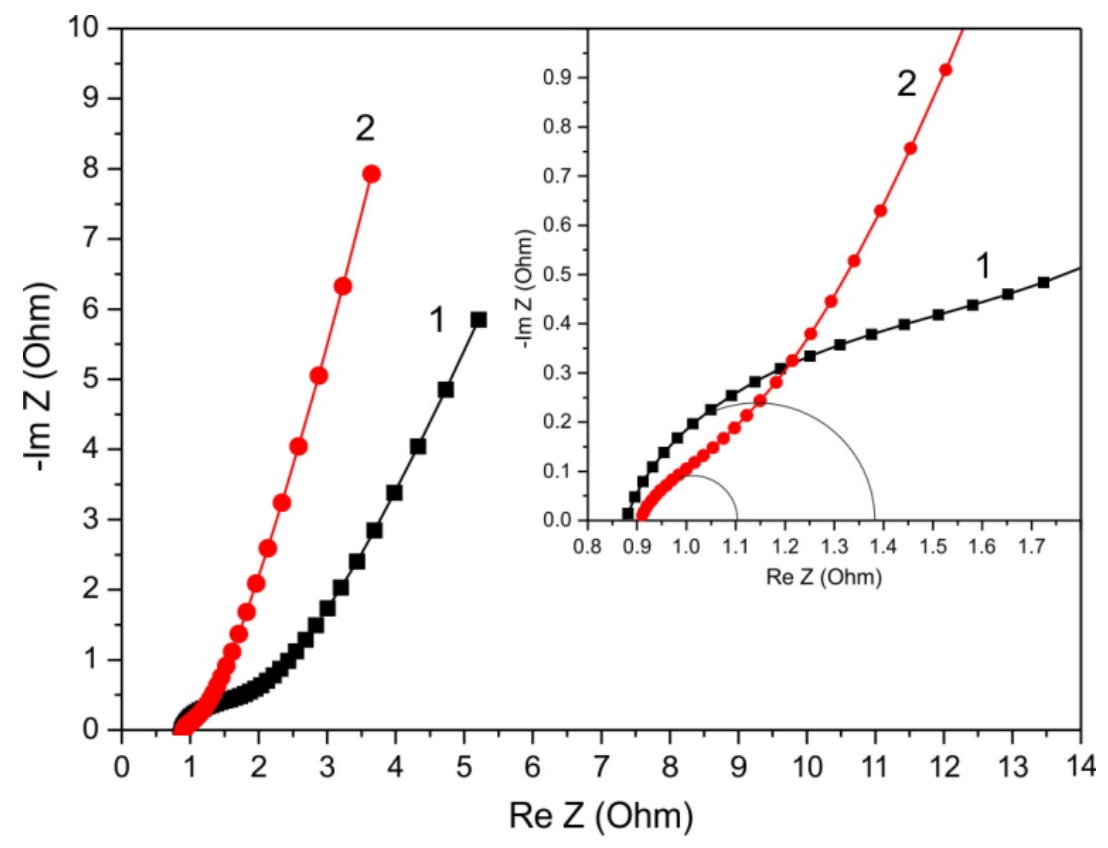

Figure 7. Nyquist plots of $\mathrm{Co}_{3} \mathrm{O}_{4}(\mathbf{1})$ and $\mathrm{Re}-\mathrm{Co}_{3} \mathrm{O}_{4}(2)$ electrodes in the frequency range of $1-10^{5} \mathrm{~Hz}$; the inset indicates the Nyquist plots at high frequency region.

The intersection of the impedance spectra on the Re $Z$ axis in the high-frequency region gives the value of equivalent series resistance $\left(R_{\mathrm{s}}\right)$ for the electrodes, which is a combination of the ionic resistance of the electrolyte, the internal resistance of the electrode material and the electrode/electrolyte interfacial contact resistance. The $R_{\mathrm{S}}$ value for the $\mathrm{Re}-\mathrm{Co}_{3} \mathrm{O}_{4}$ electrode $(0.90 \mathrm{Ohm})$ is almost the same 
as the $R_{\mathrm{s}}$ value for the $\mathrm{Co}_{3} \mathrm{O}_{4}$ electrode $(0.87 \mathrm{Ohm})$ despite the fact that the wettability of the $\mathrm{Co}_{3} \mathrm{O}_{4}$ electrode is significantly higher than that of $\mathrm{Re}^{-} \mathrm{Co}_{3} \mathrm{O}_{4}[80,81]$.

In the low frequency range, the slope of the straight line corresponding to the $\mathrm{Re}-\mathrm{Co}_{3} \mathrm{O}_{4}$ electrode is significantly higher than that of the $\mathrm{Co}_{3} \mathrm{O}_{4}$ electrode, indicating the resistance of ion diffusion in the $\mathrm{Re}-\mathrm{Co}_{3} \mathrm{O}_{4}$ electrode is lower than that of $\mathrm{Co}_{3} \mathrm{O}_{4}$. This demonstrates that the charge storage process in the $\mathrm{Re}-\mathrm{Co}_{3} \mathrm{O}_{4}$ sample is more capacitive in nature than in $\mathrm{Co}_{3} \mathrm{O}_{4}$.

Cycling stability of the capacitor is an important parameter for its practical application. Figure 8 shows that a capacity retention of $95 \%$ was obtained after 1000 charge/discharge cycles for the $\mathrm{Re}-\mathrm{Co}_{3} \mathrm{O}_{4}$ electrode at a current density of $12 \mathrm{~A} \mathrm{~g}^{-1}$. It can be seen that during the first $\sim 300$ cycles, the capacity dropped by about $5 \%$, and then remained constant indicating a good stability for the electrode with cycling.

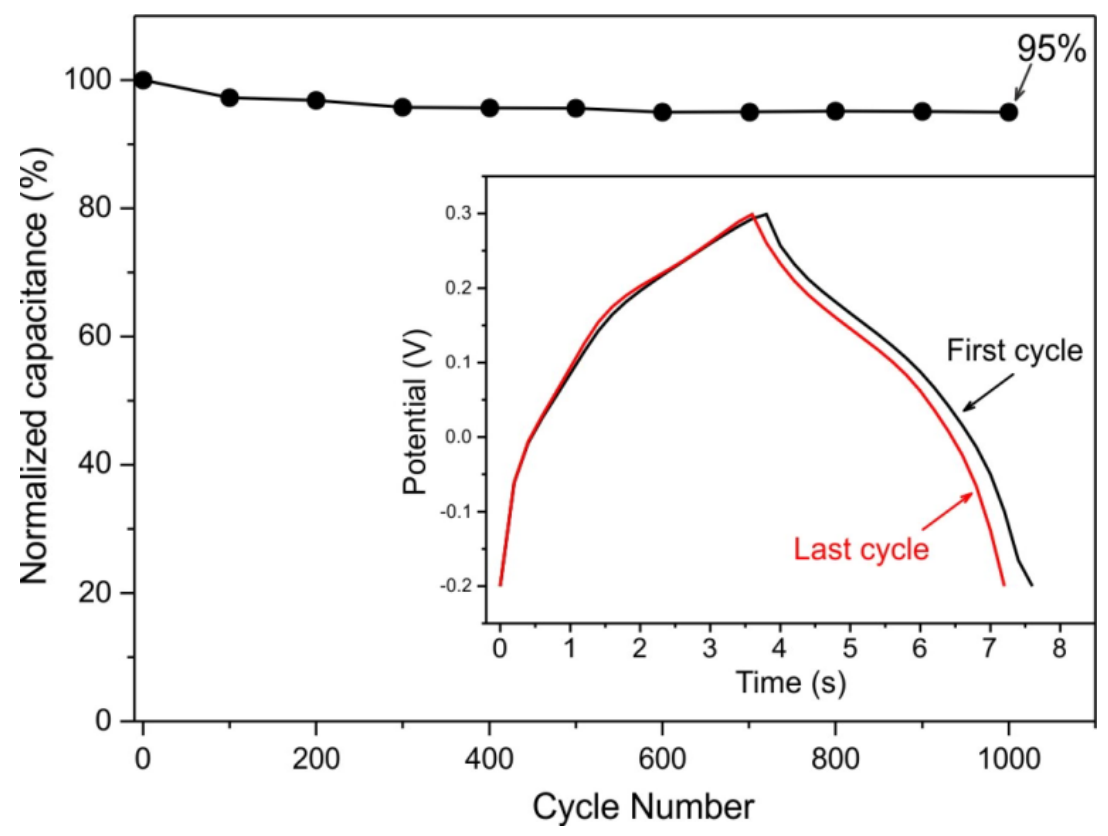

Figure 8. Cycling stability of the $\mathrm{Re}-\mathrm{Co}_{3} \mathrm{O}_{4}$ electrode tested at a current density of $12 \mathrm{~A} \mathrm{~g}^{-1}$. The inset shows the GCD curves at a current of $12 \mathrm{~A} \mathrm{~g}^{-1}$ during the first and last cycles.

In the experiments described above, the powder $\mathrm{Co}_{3} \mathrm{O}_{4}$ samples were first reduced by annealing in hydrogen and then electrodes were fabricated. Additional experiments were also carried out to study the electrochemical property of a manufactured $\mathrm{Co}_{3} \mathrm{O}_{4}$ electrode before and after hydrogen reduction. Figure 9 shows the GCD and EIS curves of the $\mathrm{Co}_{3} \mathrm{O}_{4}$ electrode before and after annealing in hydrogen. As can be seen from Figure 9 a, the capacity of the $\mathrm{Co}_{3} \mathrm{O}_{4}$ electrode is increased about four times after hydrogen reduction. Figure $9 \mathrm{~b}$ shows that the charge-transfer resistance $R_{\mathrm{ct}}$ is decreased significantly, and the slope of straight line at low frequency region of the EIS spectrum is increased as a result of hydrogen reduction. This indicates improvement in the capacitive behavior and the ion diffusion resistance of the $\mathrm{Re}-\mathrm{Co}_{3} \mathrm{O}_{4}$ electrode compared with those in the $\mathrm{Co}_{3} \mathrm{O}_{4}$ electrode before reduction.

The results of $\mathrm{CV}$, EIS and GCD measurements show that reduced $\mathrm{Co}_{3} \mathrm{O}_{4}$ provides significantly better electrochemical charge storage characteristics than the initial $\mathrm{Co}_{3} \mathrm{O}_{4}$ sample. The greater capacity of the $\mathrm{Re}-\mathrm{Co}_{3} \mathrm{O}_{4}$ sample compared with the capacity of $\mathrm{Co}_{3} \mathrm{O}_{4}$ sample can be attributed to the capacitive redox reactions associated with a thin submicron layer composed of various oxide and hydroxide spices covering the surface of metallic-Co particles obtained as a result of hydrogen reduction process. This layer is formed due to both natural oxidation and anodic oxidation during cyclic voltammetry measurements. The presence of oxide and hydroxide spices provides a wide range of redox reactions. This is evidenced by a significantly larger number of peaks on the CV curves corresponding to redox couples. The small thickness of the oxide/hydroxide layer provides a high diffusion rate of ions 
involved in redox reactions resulting in rapid kinetics of these reactions and low series resistance of the electrode. Therefore, applying metal particles instead of oxide particles in some cases can provide significant advantages in the manufacture of electrodes for high energy supercapacitors.
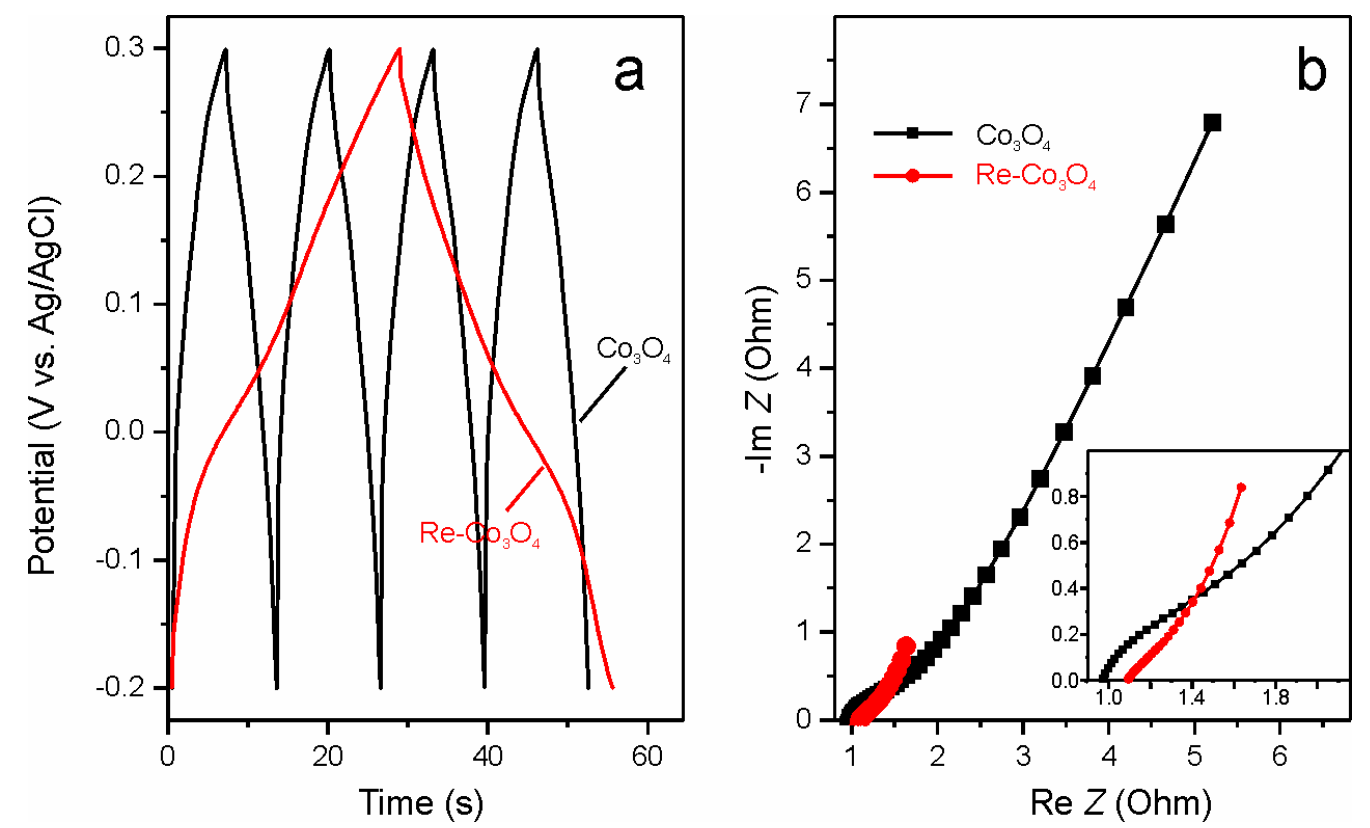

Figure 9. The GCD curves at a current density of $2 \mathrm{~A} \mathrm{~g}^{-1}(\mathbf{a})$ and Nyquist plots $(\mathbf{b})$ of $\mathrm{Co}_{3} \mathrm{O}_{4}$ electrode and the same electrode after reduction in $\mathrm{H}_{2}\left(\mathrm{Re}-\mathrm{Co}_{3} \mathrm{O}_{4}\right)$, the inset indicates the Nyquist plots at high frequency region.

Urso et al. have also reported [82] a novel electrode material consisting of $\mathrm{Ni}(\mathrm{OH})_{2} @ \mathrm{Ni}$ core-shell nanochains with promising high-rate energy storage performance. These discovered features of the $\mathrm{Ni}(\mathrm{OH})_{2} @ \mathrm{Ni}$ core-shell nanochains obtained by reduction in forming gas are explained by the quicker electron transport, greater electric field and better use of the active material when compared with those of similar $\mathrm{NiO}$ and $\mathrm{Ni}(\mathrm{OH})_{2}$-based nanostructures. Our results on enhancing the electrochemical activity of reduced cobalt oxide electrodes presented in this work largely coincide with these results.

\section{Conclusions}

In summary, a new effect of a significant increase in the electrochemical activity of reduced $\mathrm{Co}_{3} \mathrm{O}_{4}$ electrodes is demonstrated in the present work. It is shown that the reduced $\mathrm{Co}_{3} \mathrm{O}_{4}$ can ensure a higher storage capacity compared to the initial $\mathrm{Co}_{3} \mathrm{O}_{4}$ due to the presence of different forms of oxide and hydroxide spices formed on the surface of metallic Co particles. These spices provide a wide range of reversible redox reactions, all contributing to the overall storage capacity of the $\mathrm{Re}-\mathrm{Co}_{3} \mathrm{O}_{4}$ electrode. In addition to these, the small thickness of the oxide/hydroxide layer provides a high reaction rate, and the presence of a metal skeleton leads to a low series resistance of the electrode. The proposed simple method can be applied to other metal oxides (e.g., nickel [82] or tungsten [83]) which are able to recover under a hydrogen atmosphere, as well as to $\mathrm{Co}_{3} \mathrm{O}_{4}$ electrodes obtained by other methods.

Author Contributions: Measurements, N.A., Z.K., A.T., S.N.; validation, M.M., M.G., K.A. All authors have read and agreed to the published version of the manuscript.

Funding: This research was funded by Ministry of Education and Science of the Republic of Kazakhstan, grant number AP05130100.

Conflicts of Interest: The authors declare that they have no conflict of interest. 


\section{References}

1. Mirzaeian, M.; Abbas, Q.; Ogwu, A.; Hall, P.J.; Goldin, M.; Mirzaeian, M.; Jirandehi, H.F. Electrode and electrolyte materials for electrochemical capacitors. Int. J. Hydrogen Energy 2007, 42, 25565-25587. [CrossRef]

2. Mirzaeian, M.; Hall, P.J. High capacity carbon based electrodes for lithium/oxygen batteries. J. Power Syst. Technol. 2007, 31, 90-96.

3. Da, Y.; Liu, J.; Zhou, L.; Zhu, X.; Chen, X.; Fu, L. Engineering 2D Architectures toward high-performance micro-supercapacitors. Adv. Mater. 2019, 31, 1802793. [CrossRef]

4. Yu, A.; Chen, Z.; Maric, R.; Zhang, L.; Zhang, J.; Yan, J. Electrochemical supercapacitors for energy storage and delivery-Advanced materials, technologies and applications. Appl. Energy 2015, 153, 1-2. [CrossRef]

5. González, A.; Goikolea, E.; Barrena, J.A.; Mysyk, R. Review on supercapacitors: Technologies and materials. Renew. Sustain. Energy Rev. 2016, 58, 1189-1206. [CrossRef]

6. Huang, M.; Zhang, Y.X.; Li, F.; Zhang, Y.; Wen, Z.; Liu, Q. Facile synthesis of hierarchical $\mathrm{Co}_{3} \mathrm{O}_{4} @ \mathrm{MnO}_{2}$ core-shell arrays on $\mathrm{Ni}$ foam for asymmetric supercapacitors. J. Power Sources 2014, 252, 98-106. [CrossRef]

7. Lokhande, C.D.; Dubal, D.P.; Joo, O.-S. Metal oxide thin film based supercapacitors. Curr. Appl. Phys. 2011, 11, 255-270. [CrossRef]

8. Li, H.; Wang, R.; Cao, R. Physical and electrochemical characterization of hydrous ruthenium oxide/ordered mesoporous carbon composites as supercapacitor. Microporous Mesoporous Mater. 2008, 111, 32-38. [CrossRef]

9. Wu, M.; Gao, J.; Zhang, S.; Chen, A. Synthesis and characterization of aerogel-like mesoporous nickel oxide for electrochemical supercapacitors. J. Porous Mater. 2006, 13, 407-412. [CrossRef]

10. Wang, G.; Zhang, L.; Zhang, J. A review of electrode materials for electrochemical supercapacitors. Chem. Soc. Rev. 2012, 41,797-828. [CrossRef]

11. Rahmanifar, M.S.; Hemmati, M.; Noori, A.; El-Kady, M.F.; Mousavi, M.F.; Kaner, R.B. Asymmetric supercapacitors: An alternative to activated carbon negative electrodes based on earth abundant elements. Mater. Today Energy 2019, 12, 26-36. [CrossRef]

12. Oje, A.I.; Ogwu, A.; Mirzaeian, M.; Oje, A.; Tsendzughul, N. Silver thin film electrodes for supercapacitor application. Appl. Surf. Sci. 2019, 488, 142-150. [CrossRef]

13. Choudhary, N.; Li, C.; Moore, J.; Nagaiah, N.; Zhai, L.; Jung, Y.; Thomas, J. Supercapacitors: Asymmetric Supercapacitor Electrodes and Devices. Adv. Mater. 2017, 29, 1605336. [CrossRef] [PubMed]

14. Wang, S.-Y.; Ho, K.-C.; Kuo, S.-L.; Wu, N.-L. Investigation on capacitance mechanisms of $\mathrm{Fe}_{3} \mathrm{O}_{4}$ electrochemical capacitors. J. Electrochem. Soc. 2006, 153, A75-A80. [CrossRef]

15. Patil, U.M.; Salunkhe, R.R.; Gurav, K.V.; Lokhande, C.D. Chemically deposited nanocrystalline NiO thin films for supercapacitor application. Appl. Surf. Sci. 2008, 255, 2603-2607. [CrossRef]

16. Yang, Z.; Xu, F.; Zhang, W.; Mei, Z.; Pei, B.; Zhu, X. Controllable preparation of multishelled NiO hollow nanospheres via layer-by-layer self-assembly for supercapacitor application. J. Power Sources 2014, 246, $24-31$. [CrossRef]

17. Kandalkar, S.G.; Lokhande, C.D.; Mane, R.S.; Han, S.-H. A non-thermal chemical synthesis of hydrophilic and amorphous cobalt oxide films for supercapacitor application. Appl. Surf. Sci. 2007, 253, 3952-3956. [CrossRef]

18. Wang, Y.; Pan, A.; Zhu, Q.; Nie, Z.; Zhang, Y.; Tang, Y.; Liang, S.; Cao, G. Facile synthesis of nanorod-assembled multi-shelled $\mathrm{Co}_{3} \mathrm{O}_{4}$ hollow microspheres for high-performance supercapacitors. J. Power Sources 2014, 272, 107-112. [CrossRef]

19. Oje, A.I.; Ogwu, A.; Mirzaeian, M.; Tsendzughul, N. Electrochemical energy storage of silver and silver oxide thin films in an aqueous $\mathrm{NaCl}$ electrolyte. J. Electroanal. Chem. 2018, 829, 59-68. [CrossRef]

20. Liu, K.-Y.; Zhang, Y.; Zhang, W.; Zheng, H.; Su, G. Charge-discharge process of $\mathrm{MnO}_{2}$ supercapacitor. Trans. Nonferrous Met. Soc. China 2007, 17, 649-653. [CrossRef]

21. Pendashteh, A.; Mousavi, M.F.; Rahmanifar, M. Fabrication of anchored copper oxide nanoparticles on graphene oxide nanosheets via an electrostatic coprecipitation and its application as supercapacitor. Electrochim. Acta 2013, 88, 347357. [CrossRef]

22. Patake, V.; Lokhande, C.; Joo, O.S. Electrodeposited ruthenium oxide thin films for supercapacitor effect of surface treatments. Appl. Surf. Sci. 2009, 255, 4192-4196. [CrossRef]

23. Wang, P.; Liu, H.; Xu, Y.; Chen, Y.; Yang, J.; Tan, Q. Supported ultrafine ruthenium oxides with specific capacitance up to $1099 \mathrm{~F}$ g-1 for a supercapacitor. Electrochim. Acta 2016, 194, 211-218. [CrossRef] 
24. Wang, Y.; Guo, J.; Wang, T.; Shao, J.; Wang, D.; Yang, Y. Mesoporous transition metal oxides for supercapacitors. Nanomaterials 2015, 5, 1667-1689. [CrossRef] [PubMed]

25. Jayalakshmi, M.; Rao, M.M.; Venugopal, N.; Kim, K.-B. Hydrothermal synthesis of $\mathrm{SnO}_{2}-\mathrm{V}_{2} \mathrm{O}_{5}$ mixed oxide and electrochemical screening of carbon nano-tubes (CNT), $\mathrm{V}_{2} \mathrm{O}_{5}, \mathrm{~V}_{2} \mathrm{O}_{5}-\mathrm{CNT}$, and $\mathrm{SnO}_{2}-\mathrm{V}_{2} \mathrm{O}_{5}-\mathrm{CNT}$ electrodes for supercapacitor applications. J. Power Sources 2007, 166, 578-583. [CrossRef]

26. Li, X.; Xiong, S.; Li, J.; Bai, J.; Qian, Y. Mesoporous NiO ultrathin nanowire networks topotactically transformed from a-Ni(OH $)_{2}$ hierarchical microspheres and their superior electrochemical capacitance properties and excellent capability for water treatment. J. Mater. Chem. 2012, 22, 14276-14283. [CrossRef]

27. Pavasupree, S.; Suzuki, Y.; Kitiyanan, A.; Pivsa-Art, S.; Yoshikawa, S. Synthesis and characterization of vanadium oxides nanorods. J. Solid State Chem. 2005, 178, 2152-2158. [CrossRef]

28. Jia, C.J.; Sun, L.D.; Yan, Z.G.; You, L.P.; Luo, F.; Han, X.D.; Pang, Y.C.; Zhang, Z.; Yan, C.H. Single-crystalline iron oxide nanotubes. Angew. Chem. 2005, 44, 4328-4333. [CrossRef]

29. Cao, J.; Wang, Y.; Ma, T.; Liu, Y.; Yuan, Z. Synthesis of porous hematite nanorods loaded with CuO nanocrystals as catalysts for CO oxidation. J. Nat. Gas Chem. 2011, 20, 669-676. [CrossRef]

30. Liu, F.; Yuan, W.; Li, T.; Zhang, Z. Synthesis and electrochemical performance of mesoporous nickel oxide using mixed surfactant template. Mater. Res. Innov. 2015, 19, 70-75. [CrossRef]

31. Wang, Y.; Chang, B.; Guan, D.; Pei, K.; Chen, Z.; Yang, M.; Dong, X. Preparation of nanospherical porous $\mathrm{NiO}$ by a hard template route and its supercapacitor application. Mater. Lett. 2014, 135, 172-175. [CrossRef]

32. Kim, S.-I.; Lee, J.-S.; Ahn, H.-J.; Song, H.-K.; Jang, J.-H. Facile route to an efficient NiO supercapacitor with a three-dimensional nanonetwork morphology. ACS Appl. Mater. Interfaces 2013, 5, 1596-1603. [CrossRef] [PubMed]

33. Woo, K.; Lee, H.; Ahn, J.-P.; Park, Y. Sol-Gel Mediated Synthesis of $\mathrm{Fe}_{2} \mathrm{O}_{3}$ Nanorods. Adv. Mat. 2003, 15, 1761-1764. [CrossRef]

34. Jagtap, S.V.; Tale, A.S.; Thakre, S.D. Synthesis by sol gel method and characterization of $\mathrm{Co}_{3} \mathrm{O}_{4}$ nanoparticles. Int. J. Res. Eng. Appl. Sci. 2017, 7, 1-6.

35. Huang, Y.-Y.; Lin, L.-Y. Synthesis of ternary metal oxides for battery-supercapacitor hybrid devices: Influences of metal species on redox reaction and electrical conductivity. ACS Appl. Energy Mater. 2018, 1, 2979-2990. [CrossRef]

36. Kou, T.; Yao, B.; Liu, T.; Li, Y. Recent advances in chemical methods for activating carbon and metal oxide based electrodes for supercapacitors. J. Mater. Chem. A 2017, 5, 17151. [CrossRef]

37. Kate, R.S.; Khalate, S.A.; Deokate, R.J. Overview of nanostructured metal oxides and pure nickel oxide (NiO) electrodes for supercapacitors: A review. J. Alloy. Compd. 2018, 734, 89-111. [CrossRef]

38. Tao, L.; Shengjun, L.; Bowen, Z.; Bei, W.; Dayong, N.; Zeng, C.; Ying, Y.; Ning, W.; Zhang, W.-F. Supercapacitor electrode with a homogeneously $\mathrm{Co}_{3} \mathrm{O}_{4}$-coated multiwalled carbon nanotube for a high capacitance. Nanoscale Res. Lett. 2015, 10, 1-7. [CrossRef]

39. Pawar, S.M.; Kim, J.; Inamdar, A.I.; Woo, H.; Jo, Y.; Pawar, B.S.; Cho, S.; Kim, H.; Im, H. Multi-functional reactively-sputtered copper oxide electrodes for supercapacitor and electro-catalyst in direct methanol fuel cell applications. Sci. Rep. 2016, 6, 21310. [CrossRef]

40. Montemor, M.F.; Eugénio, S.; Tuyen, N.; Silva, R.P.; Silva, T.M.; Carmezim, M.J. Nanostructured transition metal oxides produced by electrodeposition for application as redox electrodes for supercapacitors. In Handbook of Nanoelectrochemistry; Springer: Berlin/Heidelberg, Germany, 2016; pp. 681-714.

41. Abbas, Q.; Mirzaeian, M.; Ogwu, A.A. Electrochemical performance of controlled porosity resorcinol/formaldehyde based carbons as electrode materials for supercapacitor applications. Int. J. Hydrogen Energy 2017, 42, 25588-25597. [CrossRef]

42. Mirzaeian, M.; Abbas, Q.; Gibson, D.; Mazur, M. Effect of nitrogen doping on the electrochemical performance of resorcinol-formaldehyde based carbon aerogels as electrode material for supercapacitor applications. Energy 2019, 173, 809-819. [CrossRef]

43. Abbas, Q.; Mirzaeian, M.; Ogwu, A.A.; Mazur, M.; Gibson, D. Effect of physical activation/surface functional groups on wettability and electrochemical performance of carbon/activated carbon aerogels based electrode materials for electrochemical capacitors. Int. J. Hydrogen Energy 2020, 45, 13586-13595. [CrossRef]

44. Sun, G.; Ma, L.; Ran, J.; Shen, X.; Tong, H. Incorporation of homogeneous $\mathrm{Co}_{3} \mathrm{O}_{4}$ into a nitrogen-doped carbon aerogel via a facile in situ synthesis method: Implications for high performance asymmetric supercapacitors. J. Mater. Chem. A 2016, 4, 9542-9554. [CrossRef] 
45. Raj, R.P.; Ragupathy, P.; Mohan, S. Remarkable capacitive behavior of a $\mathrm{Co}_{3} \mathrm{O}_{4}$-polyindole composite as electrode material for supercapacitor applications. J. Mater. Chem. A 2015, 3, 24338-24348. [CrossRef]

46. Vilian, A.T.E.; Dinesh, B.; Rethinasabapathy, M.; Hwang, S.-K.; Jin, C.-S.; Huh, Y.S.; Han, Y.-K. Hexagonal $\mathrm{Co}_{3} \mathrm{O}_{4}$ anchored reduced graphene oxide sheets for high-performance supercapacitors and non-enzymatic glucose sensing. J. Mater. Chem. A 2018, 6, 14367-14379. [CrossRef]

47. Nagajyothi, P.; Pandurangan, M.; Sreekanth, T.V.M.; Shim, J.; Tvm, S. One-step engineered self-assembly $\mathrm{Co}_{3} \mathrm{O}_{4}$ nanoparticles to nanocubes for supercapacitors. Mater. Res. Express 2018, 5, 025511. [CrossRef]

48. Ma, L.; Fan, H.; Wei, X.; Chen, S.; Hu, Q.; Liu, Y.; Zhi, C.; Lu, W.; Zapien, J.A.; Huang, H. Towards high areal capacitance, rate capability and tailorable supercapacitor: $\mathrm{Co}_{3} \mathrm{O}_{4} @$ Polypyrrole core-shell nanorod bundle arrays electrode. J. Mater. Chem. A 2018, 6, 19058-19065. [CrossRef]

49. Zhang, Y.; Li, L.; Shi, S.; Xiong, Q.; Zhao, X.; Wang, X.; Gu, C.; Tu, J. Synthesis of porous $\mathrm{Co}_{3} \mathrm{O}_{4}$ nanoflake array and its temperature behavior as pseudo-capacitor electrode. J. Power Sources 2014, 256, 200-205. [CrossRef]

50. Jafarian, M.; Mahjani, M.; Heli, H.; Gobal, F.; Khajehsharifi, H.; Hamedi, M. A study of the electro-catalytic oxidation of methanol on a cobalt hydroxide modified glassy carbon electrode. Electrochim. Acta 2003, 48, 3423-3429. [CrossRef]

51. Huang, Y.; Liang, J.; Chen, Y. An overview of the applications of graphene-based materials in supercapacitors. Small 2012, 8, 1805-1834. [CrossRef]

52. An, C.; Zhang, Y.; Guo, H.; Wang, Y. Metal oxide-based supercapacitors: Progress and prospectives. Nanoscale Adv. 2019, 1, 4644-4658. [CrossRef]

53. Uke, S.J.; Akhare, V.P.; Bambole, D.R.; Bodade, A.B.; Chaudhari, G.N. Recent advancements in the cobalt oxides, manganese oxides, and their composite as an electrode material for supercapacitor: A review. Front. Mater. 2017, 1, 1-6. [CrossRef]

54. Kebabsa, L.; Kim, J.; Lee, D.; Lee, B. Highly porous cobalt oxide-decorated carbon nanofibers fabricated from starch as free-standing electrodes for supercapacitors. Appl. Surf. Sci. 2020, 511, 145313. [CrossRef]

55. Numan, A.; Duraisamy, N.; Omar, F.S.; Mahipal, Y.K.; Ramesh, S.; Ramesh, S. Enhanced electrochemical performance of cobalt oxide nanocube intercalated reduced graphene oxide for supercapacitor application. RSC Adv. 2016, 6, 34894-34902. [CrossRef]

56. Williamson, G.; Hall, W. X-ray line broadening from filed aluminum and wolfram. Acta Metall. 1953, 1, 22-31. [CrossRef]

57. Shults, J.F.; Hofer, L.J.E.; Cohn, E.M.; Stein, K.C.; Anderson, R.B. Synthetic Liquid Fuels from Hydrogenation of Carbon Monoxide; Technical paper 700: 1-15; U.S. Bureau of Mines: Washington, DC, USA, 1959.

58. Hadjiev, V.G.; Iliev, M.N.; Vergilov, I.V. The Raman spectra of $\mathrm{Co}_{3} \mathrm{O}_{4}$. J. Phys. C Solid State Phys. 1988, 21, L199-L201. [CrossRef]

59. Gallant, D.; Pézolet, M.; Simard, S. Optical and physical properties of cobalt oxide films electrogenerated in bicarbonate aqueous media. J. Phys. Chem. 2006, 110, 6871-6880. [CrossRef]

60. Lorite, I.; Romero, J.J.; Fernández, J.F. Effects of the agglomeration state on the Raman properties of $\mathrm{Co}_{3} \mathrm{O}_{4}$ nanoparticles. J. Raman Spectrosc. 2012, 43, 1443-1448. [CrossRef]

61. Samal, R.; Dash, B.; Sarangi, C.K.; Sanjay, K.; Subbaiah, T.; Senanayake, G.; Minakshi, M. Influence of synthesis temperature on the growth and surface morphology of $\mathrm{Co}_{3} \mathrm{O}_{4}$ nanocubes for supercapacitor applications. Nanomaterials 2017, 7, 356. [CrossRef]

62. Premlatha, S.; Chandrasekaran, M.; Bapu, G.N.K.R. Preparation of cobalt- $\mathrm{RuO}_{2}$ nanocomposite modified electrode for highly sensitive and selective determination of hydroxylamine. Sens. Actuators B 2017, 252, 375-384. [CrossRef]

63. Hao, Y.; Wang, H.; Hu, Z.; Gan, L.; Xu, Z. Facile synthesis of mesoporous cobalt oxide rugby balls for electrochemical energy storage. New J. Chem. 2015, 39, 68-71. [CrossRef]

64. Naseri, N.; Esfandiar, A.; Qorbani, M.; Moshfegh, A. Selecting support layer for electrodeposited efficient cobalt oxide/hydroxide nanoflakes to split water. ACS Sustain. Chem. Eng. 2016, 4, 3151-3159. [CrossRef]

65. Qorbani, M.; Naseri, N.; Moshfegh, Z. Hierarchical $\mathrm{Co}_{3} \mathrm{O}_{4} / \mathrm{Co}(\mathrm{OH})_{2}$ nanoflakes as a supercapacitor electrode: Experimental and semi-empirical model. ACS Appl. Mater. Interfaces 2015, 7, 11172-11179. [CrossRef] [PubMed]

66. Ma, L.; Zhou, H.; Shen, X.; Chen, Q.; Zhu, G.-X.; Ji, Z. Facile synthesis of $\mathrm{Co}_{3} \mathrm{O}_{4}$ porous nanosheets/reduced graphene oxide composites and their excellent supercapacitor performance. RCS Adv. 2014, 4, 53180-53187. [CrossRef] 
67. Gomez-Meier, H.; Vilche, J.; Arvia, A. The electrochemical behaviour of cobalt in alkaline solutions Part I. The potentiodynamic response in the potential region of the Co/CoO couple. J. Electroanal. Chem. 1982, 134, 251-272. [CrossRef]

68. Meier, H.; Vilche, J.; Arvia, A. The electrochemical behaviour of cobalt in alkaline solutions part II. The potentiodynamic response of $\mathrm{Co}(\mathrm{OH})_{2}$ electrodes. J. Electroanal. Chem. Interfacial Electrochem. 1982, 138, 367-379. [CrossRef]

69. Cowling, R.; Riddiford, A. The anodic behaviour of cobalt in alkaline solutions. Electrochim. Acta 1969, 14, 981-989. [CrossRef]

70. Medway, S.; Lucas, C.; Kowal, A.; Nichols, R.J.; Johnson, D. In situ studies of the oxidation of nickel electrodes in alkaline solution. J. Electroanal. Chem. 2006, 587, 172-181. [CrossRef]

71. Kessler, T.; Visintin, A.; De Chialvo, M.R.; Triaca, W.E.; Arvia, A.J. The development of a cobalt oxide spinel structure overlayer on cobalt electrodes: A modified electrode surface of electrocatalytic interest. J. Electroanal. Chem. Interfacial Electrochem. 1989, 261, 315-329. [CrossRef]

72. Grden, M. Impedance study on the capacitance of silver electrode oxidised in alkaline electrolyte. J. Solid State Electrochem. 2017, 21, 3333-3344. [CrossRef]

73. Wu, X.; Xing, W.; Zhang, L.; Zhou, J.; Zhou, J.; Wang, G.; Qiao, S.Z. Nickel nanoparticles prepared by hydrazine hydrate reduction and their application in supercapacitor. Powder Technol. 2012, 224, $162-167$. [CrossRef]

74. Vittal, R.; Ho, K.-C. Cobalt oxide electrodes-problem and a solution through a novel approach using cetyltrimethylammonium bromide (CTAB). Catal. Rev. 2015, 57, 145-191. [CrossRef]

75. Augustyn, V.; Simon, P.; Dunn, B.S. Pseudocapacitive oxide materials for high-rate electrochemical energy storage. Energy Environ. Sci. 2014, 7, 1597-1614. [CrossRef]

76. Ji, X.; Hallam, P.M.; Houssein, S.M.; Kadara, R.; Lang, L.; Banks, C.E. Printable thin film supercapacitors utilizing single crystal cobalt hydroxide nanosheets. RSC Adv. 2012, 2, 1508-1515. [CrossRef]

77. Xiao, B.; Zhu, W.; Li, Z.; Zhu, J.; Zhu, X.; Pezzotti, G. Tailoring morphology of cobalt -nickel layered double hydroxide via different surfactants for high-performance supercapacitor. R. Soc. Open Sci. 2018, 5, 180867. [CrossRef] [PubMed]

78. Chu, H.; Zhu, Y.; Fang, T.; Hua, J.; Qiu, S.; Liu, H.; Qin, L.; Wei, Q.; Zou, Y.; Xiang, C.; et al. Solvothermal synthesis of cobalt nickel layered double hydroxides with a three-dimensional nanopetal structure for high-performance supercapacitors. Sustain. Energy Fuels 2020, 4, 337-346. [CrossRef]

79. Babar, P.; Lokhande, A.; Pawar, S.M.; Gang, M.; Jo, E.; Go, C.; Suryawanshi, M.P.; Kim, J.-H.; Pawar, S. Electrocatalytic performance evaluation of cobalt hydroxide and cobalt oxide thin films for oxygen evolution reaction. Appl. Surf. Sci. 2018, 427, 253-259. [CrossRef]

80. Kharade, P.; Thombare, J.V.; Babar, A.; Bulakhe, R.; Kulkarni, S.; Salunkhe, D.J. Electrodeposited nanoflakes like hydrophilic $\mathrm{Co}_{3} \mathrm{O}_{4}$ as a supercapacitor electrode. J. Phys. Chem. Solids 2018, 120, 207-210. [CrossRef]

81. Li, L.; Li, Y.; Gao, S.; Koshizaki, N. Ordered $\mathrm{Co}_{3} \mathrm{O}_{4}$ hierarchical nanorod arrays: Tunable superhydrophilicity without UV irradiation and transition to superhydrophobicity. J. Mater. Chem. 2009, 19, 8366-8371. [CrossRef]

82. Urso, M.; Torrisi, G.; Boninelli, S.; Bongiorno, C.; Priolo, F.; Mirabella, S. Ni(OH) $)_{2}$ Ni core-shell nanochains as low-cost high-rate performance electrode for energy storage applications. Sci. Rep. 2019, 9, 7736. [CrossRef]

83. Abdullin, K.A.; Kalkozova, Z.K.; Markhabayeva, A.A.; Dupre, R.; Moniruddin; Nuraje, N. Core-shell $\left(\mathrm{W} @ \mathrm{WO}_{3}\right)$ nanostructure to improve electrochemical performance. ACS Appl. Energy Mater. 2019, 2, 797-803. [CrossRef]

(C) 2020 by the authors. Licensee MDPI, Basel, Switzerland. This article is an open access article distributed under the terms and conditions of the Creative Commons Attribution (CC BY) license (http://creativecommons.org/licenses/by/4.0/). 